\title{
グラス・ファイバ・ダクト直管部の音響特性について ON SOUND CHARACTERISTICS OF STRAIGHT GLASS FIBER DUCTS
}

\author{
塩川博 義*, 板 本 守正** \\ Hiroyoshi SHIOKAWA and Morimasa ITAMOTO
}

\begin{abstract}
Sound radiation from side wall of glass fiber ducts is studied by measuring complex sound intensity in sound field outside side wall.

The sound from side wall radiates much more within about 1 meter in the length of glass fiber ducts from joint with steel ducts.

For evaluating sound characteristics of straight glass fiber ducts, nine kinds of test units (round, regular polygon and square section ducts, each of them have three kinds of ducts.) are. studied.

By the difference in their duct section types sound attenuation and sound insulation characteristics of side wall are compared and discussed.

Keywords : glass fiber duct, sound radiation, complex sound intensity, sound attenuation, sound insulation characteristics グラス・ファイバ・ダクト，音響放射，複素音響インテンシティ，音響減衰，遮音特 性
\end{abstract}

\section{1. 緒 言}

我々は，グラス・ファイバ・ダクト系の設計を合理的 に行うための基礎的な設計データを得るために，それら の気流および音響特性に関する研究1)-31を行ってきた。 その音響特性で, グラス・ファイバ・ダクト直管部を 鉄板ダクトに接続して用いるときに，ダクト断面寸法が 小さいほ亡゙, その接続直後 $1 \mathrm{~m}$ 以内の音響诚衰とそれ 以降の音響减衰に大きな差が生じることが分かった。ま た,ダクト内から外への遮音特性も鉄板ダクト接続直後 $1 \mathrm{~m}$ 以内でほぼ決まることも分かっだ”。これらは, 鉄 板ダクトから伝搬してきた音響エネルギーが，ほとんど $1 \mathrm{~m}$ 以内でダクト外へ放出されるものと考光られる。

しかし，この鉄板ダクト接続直後 $1 \mathrm{~m}$ という距離は, 実務的なダクト設計に便利なように, 測定結果から $1 \mathrm{~m}$ としているのみで, $1 \mathrm{~m}$ 前後でどのような音響放射がな されているか定かでない。

そこで，本研究では，まず，グラス・ファ.イバ・ダク 卜側壁外側の放射音場において複素音響インテンシティ を测定し，それらのべクトル・マップを作成して，1 $\mathrm{m}$ という距離が妥当かどうか検討する。

さらに,これらをふまえて,新たなグラス・ファイバ .
ダクト直管部の音響減衰とダクト側壁の遮音特性とを明 らかにし；それらを断面形状の違いにより比較検討を行 い,グラス・ファイバ・ダクト直管部の消音設計を合理 的に行うための基礎的資料としてまとめたので報告する。

\section{2. 供試体の種類}

供試体を図一1に示す。供試体は円形，多角形（正十 角形）および正方形断面ダクト直管部がそれぞれ 3 種ず つ合計 9 種類で, 以後, いずれも供試体は, 断面形状 (円 形：R, 多角形：P, 正方形：S) および断面寸法 (円 形は直径, 多角形は内接する円再の直径, 正方形は一辺の 長さ）の組合せで表す。例えば，正方形断面ダクトで断 面寸法 $200 \times 200$ は, S-200 とする。

側壁を構成するグラス・ファイバは，いずれも擪さ $25 \mathrm{~mm}$, 密度 $64 \mathrm{~kg} / \mathrm{m}^{3}$ である。外表面は, クラフト紙 をグラス・ウール表面に接着し，グラス・ヤーンおよび アルミ箔で補強しており，内表面は，円形断面ダクトは 仕上げをせず，多角形断面ダクトはグラス・シートを， 一正方形断面ダクトは不織布を張り付けて処理している。

また，各実験時におけるグラス・ファイバ・ダクトお よび鉄板ダクトの取り付け方法は，現場での施工方法之

\footnotetext{
本論文は日本建築学会において発表した文献 5) 7) の内容を再検討し，まとめ直したものである。

**日本大学生産工学部建築工学科 専任講師·工修 Lecturer, Dept. of Architectural Engineering, College of Industrial

. Technology, Nihon Univ., M. Eng.

** 日本大学生産工学部建築工学科 教授. 工博 Prof., Dept. of Architectural Engineering, College of Industrial Technolgy, Nihon Univ., Dr. Eng.
} 
同様に行う。

\section{3. ダクト側壁からの音響放射}

グラス・ファイバ・ダクト側壁外側の放射音場の測定 は，円形および正方形断面ダクトで行っており，多角形 断面ダクトの測定は行っていない。

3.1 供試体の音響特性

円形および正方形断面ダクトのダクト内法"により求 めた鉄板ダクト接続直後 $1 \mathrm{~m}$ 以内および以降の音響減 衰を図一 2 および 3 に, 残響室法" よび $4.6 \mathrm{~m}$ のダクト内から外への遮音特性（R-200, S-300 およびS-600 のみ）を図一 4 に示す。図一 2 およ び 3 によれば，鉄板ダクト接続直後 $1 \mathrm{~m}$ 以内の音響減 衰がそれ以降の音響诚衰より大きいという特徵が，断面 寸法の小さいダクトの $1 \mathrm{k}$ および $2 \mathrm{kHz}$ 帯域に顕著に見 られる。また，図一4によれば，いずれも，長さ $1 \mathrm{~m}$ お よび $4.6 \mathrm{~m}$ の遮音特性は，ほぼ同様な傾向を示す。

\section{2 実験装置および方法}

測定は無響室で行う。実験装置を図一5に示す。鉄板 ダクト上流側に取り付けたスピーカよりピンク・ノイズ を発生させ，測定面は，側壁（円形断面ダクトは側壁に

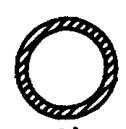

Lf

R-Type

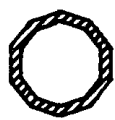

d

P-Type
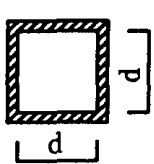

S-Type

Duct section

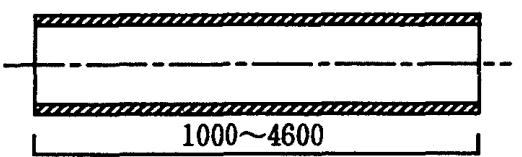

$$
1000 \sim 4600
$$

\begin{tabular}{l|c|c}
\hline $\begin{array}{l}\text { Duct } \\
\text { section }\end{array}$ & Type & $\begin{array}{l}\text { df or } \\
\mathrm{d}(\mathrm{mm})\end{array}$ \\
\hline \multirow{4}{*}{$\begin{array}{c}\text { Round } \\
\text { (R-Type) }\end{array}$} & $\mathrm{R}-300$ & $300\}$ \\
\cline { 2 - 3 } & $\mathrm{R}-600$ & $600\}$ \\
\hline \multirow{3}{*}{$\begin{array}{l}\text { Regular } \\
\text { polygon }\end{array}$} & $\mathrm{P}-200$ & 200 \\
\cline { 2 - 3 } (P-Type) & $\mathrm{P}-300$ & 300 \\
\cline { 2 - 3 } & $\mathrm{P}-600$ & 600 \\
\hline & $\mathrm{S}-200$ & 200 \\
\cline { 2 - 3 } & $\mathrm{S}-300$ & 300 \\
\hline \multirow{2}{*}{$\begin{array}{l}\text { Square } \\
\text { (S-Type) }\end{array}$} & $\mathrm{S}-600$ & 600 \\
\hline
\end{tabular}

接する面）と垂直なダクト内中心軸を含む断面内とし， 図一5に示す測定点で直交する 2 方向のアクティブおよ びリアクティブ・インテンシティ・レベルを測定する。

本来，実際の音響パワー・フローを表すのみなら，ア

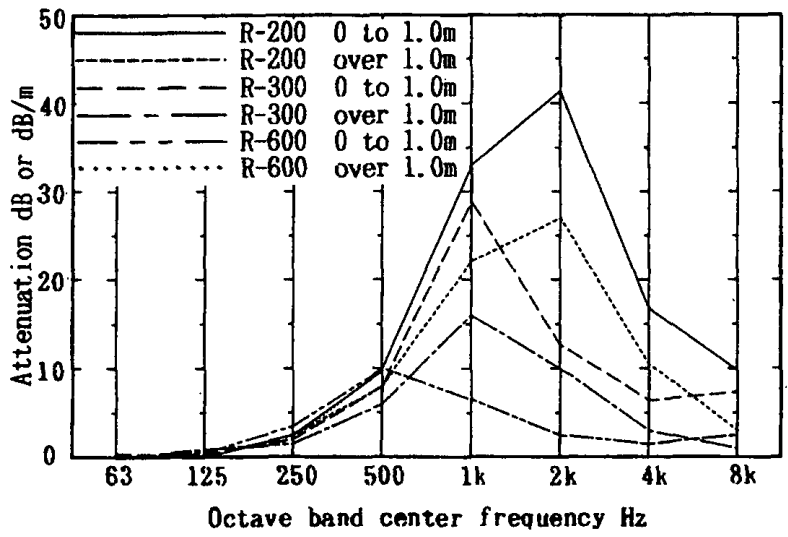

図一2 円形断面ダクトの音響减衰

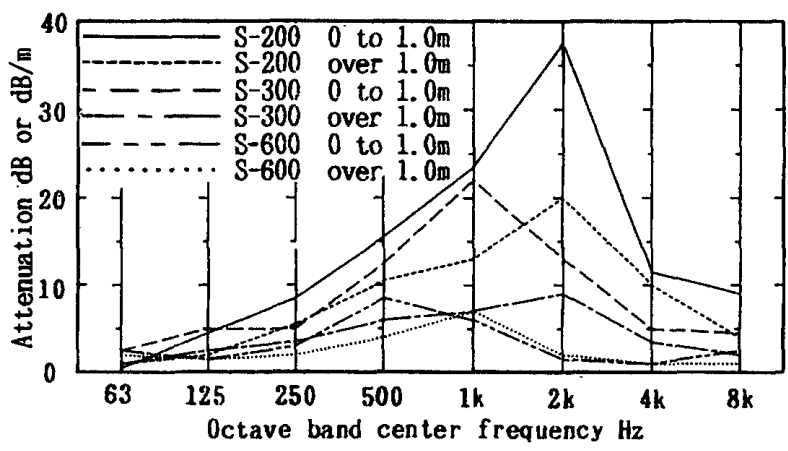

图一3 正方形断面ダクトの音響减衰

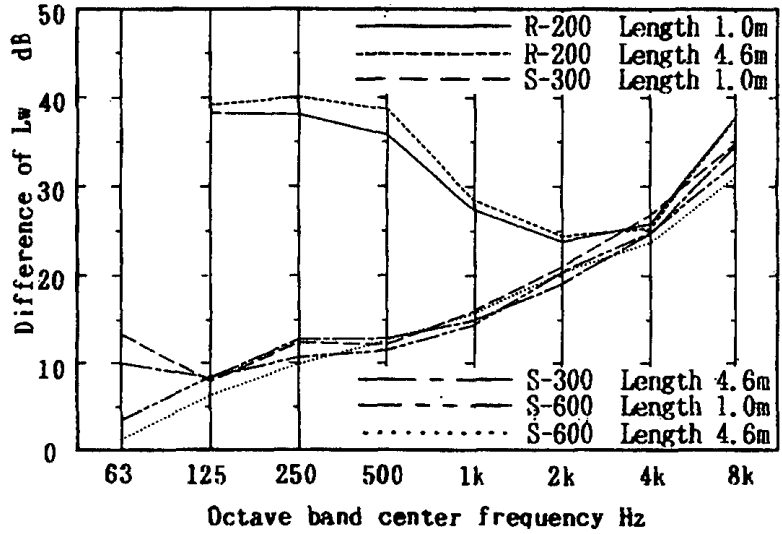

图一4 ダクト内から外へ透過する場合の遮音特性

図一1 供試体の種類

\begin{tabular}{c|c|c}
\hline Type & A & B \\
\hline $\mathrm{R}-200$ & 80 & 240 \\
\hline $\mathrm{R}-300$ & 120 & 240 \\
\hline $\mathrm{R}-600$ & 130 & 390 \\
\hline $\mathrm{S}-200$ & 100 & 225 \\
\hline $\mathrm{S}-300$ & 100 & 275 \\
\hline $\mathrm{S}-600$ & 100 & 425 \\
\hline
\end{tabular}
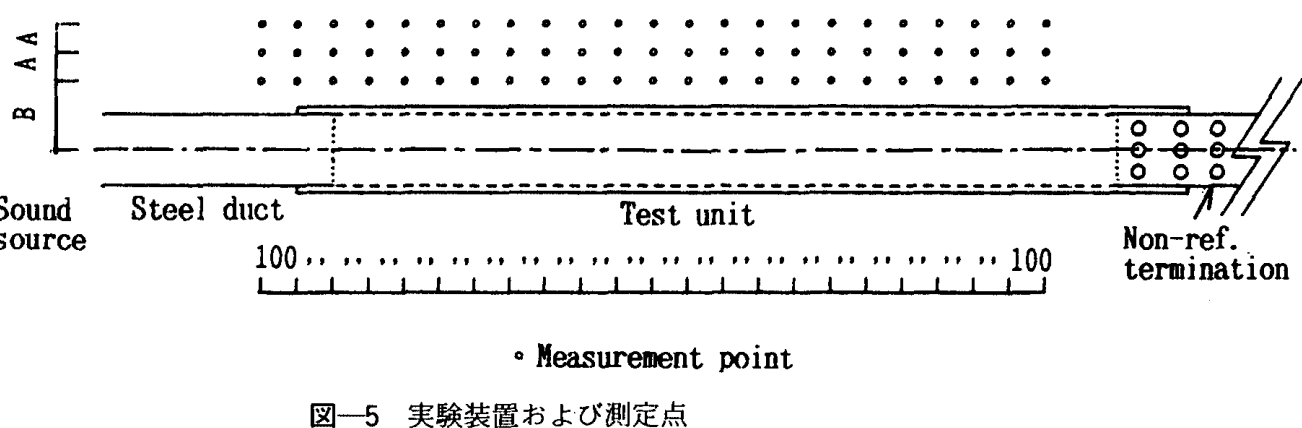

- Measurement point

图一5 実験装置および測定点 


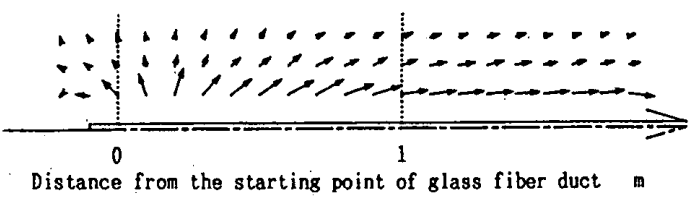

(a) Active intensity

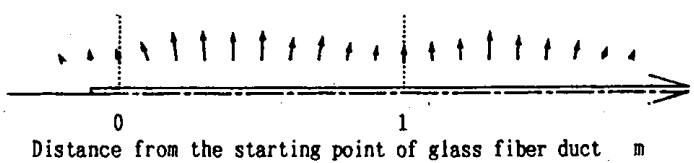

(b) Reactive intensity

図一6 R-200 のベクトル・マップ $(125 \mathrm{~Hz})$

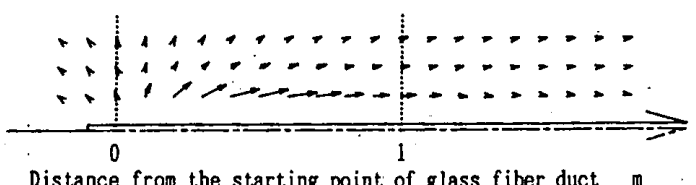

(a) Active intensity

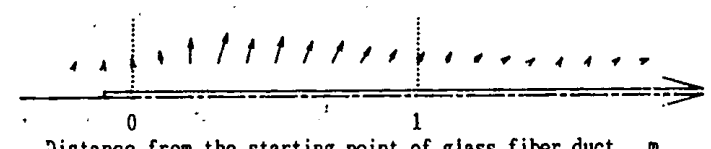

Distance from the starting point of glass fiber duct m

(b) Reactive intensity

図-7 R-200 のベクトル・マップ $(500 \mathrm{~Hz})$

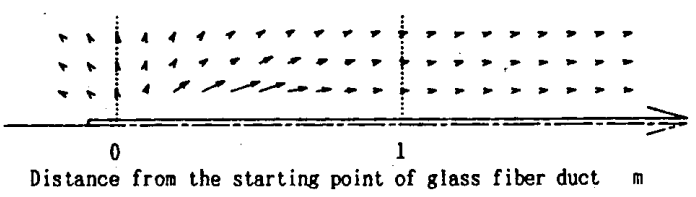

(a) Active intensity

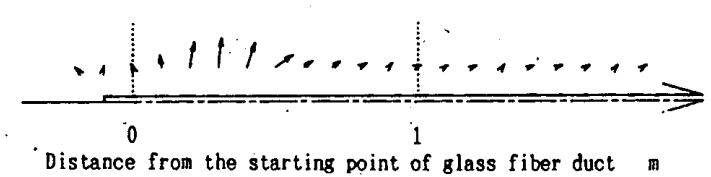

(b) Reactive intensity

図一8 R-200 のベクトル・マップ $(2 \mathrm{kHz})$

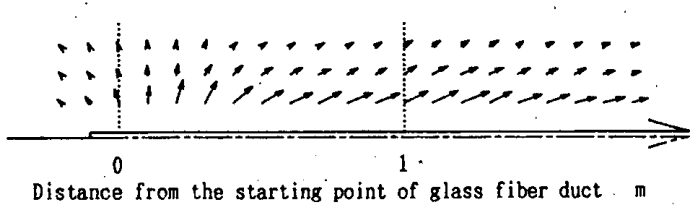

(a) Active intensity

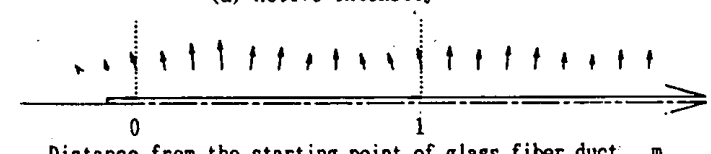

Distance from the starting point of glass fiber duct In

(b) Reactive intensity

図-9 R-300 のベクトル・マップ (125 Hz)

クティブ・インテンシティを測定すればよいが，側壁か らの音響放射の位置をより明確に把握するためにリアク

ティブ・インテンシティも同時に測定した。

3.3 測定結果および考察

軸方向における R-200 および S-200の 125，500およ び $2 \mathrm{kHz}$ 帯域， R-300 およびS-300の 125, $1 \mathrm{k}$ および 2 $\mathrm{kHz}$ 帯域, R-600 および S-600の 500 および $2 \mathrm{kHz}$ 帯 域のアクティブおよびリアクティブ・インテンシティの

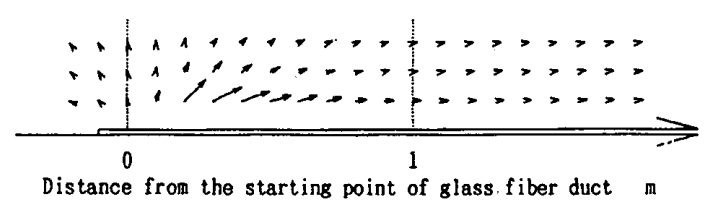

(a) Active intensity

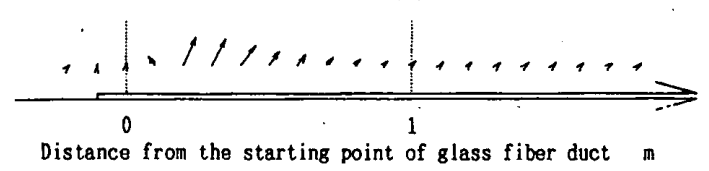

(b) Reactive intensity

図-10 R-300 のベクトル・マップ $(1 \mathrm{kHz})$

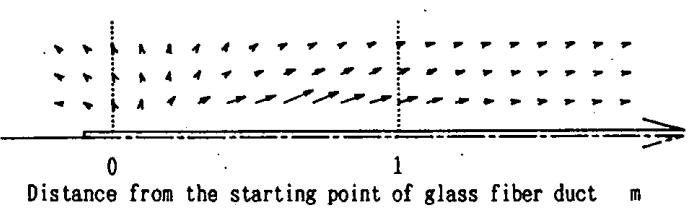

(a) Active intensity

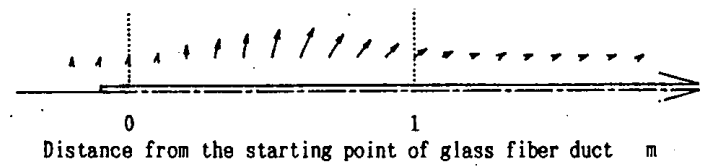

(b) Reactive intensity

図-11 R-300 のベクトル・マップ $(2 \mathrm{kHz})$

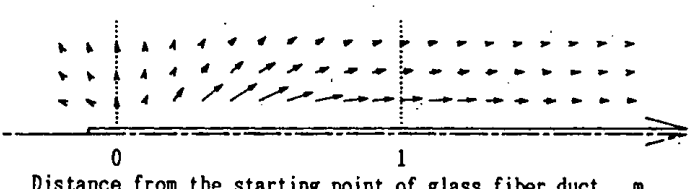

Distance from the starting point of glass fiber duct in (a) Active intensity

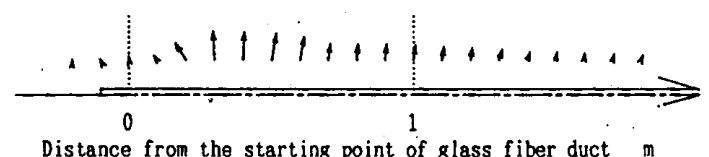

(b) Reactive intensity

図-12 R-600 のベクトル・マップ $(500 \mathrm{~Hz})$

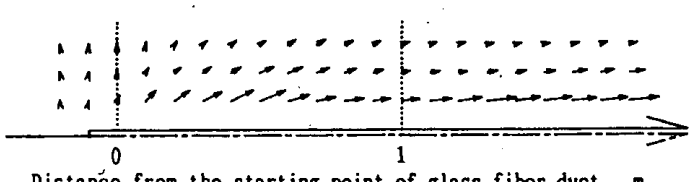

Distance from the starting point of glass fiber duct m

(a) ictive intensity

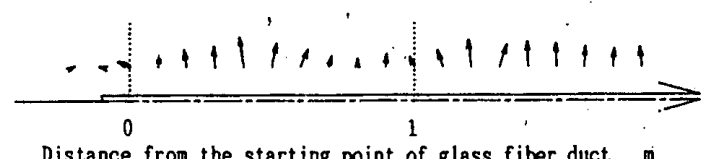

(b) Reactive intensity

図-13 R-600のベクトル・マップ (2kHz)

ベクトル・マップ (ベクトルの長さは, インテンシティ の大きさを表すが，ひとつの図の中で, 最大のものを基 準として相対的に表しているので，その図中のみ大きさ の比較ができる) を図一6〜21に示す。

リアクティブ・インテンシティは，3列とも測定を 行っているが，側壁から 2 および 3 列目では，ほぼ平面 波になるものと考えられ，いずれの図においてもリアク ティブ・インテンシティの値は测定してもほとんよ゙出て 


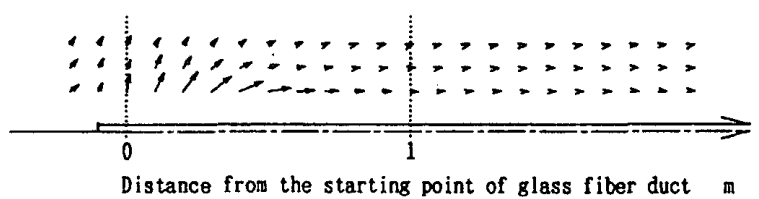

(a) Active intensity

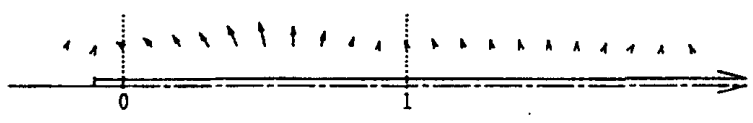

Distance from the starting point of glass fiber duct (b) Reactive intensity

图一14 S-200のベクトル・マップ $(125 \mathrm{~Hz})$

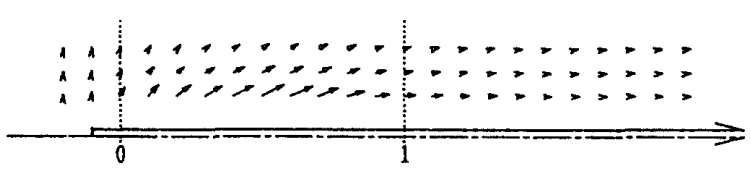

Distance from the starting point of glass fiber duct on (a) Active intensity

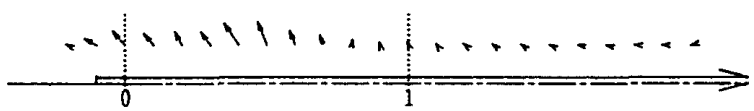

Distance from the starting point of glass fiber duct m (b) Reactive intensity

図-15 S-200のベクトル・マップ $(500 \mathrm{~Hz})$

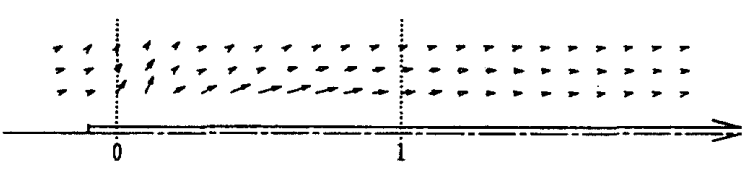

Distance from the starting point of glass fiber duct in (a) Active intensity

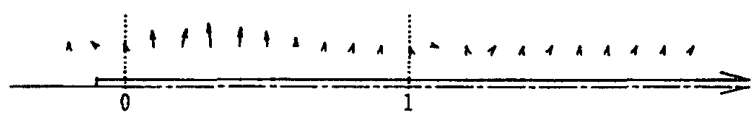

Distance from the starting point of glass fiber duct m (b) Reactive intensity

図-16 S-200のベクトル・マップ $(2 \mathrm{kHz})$

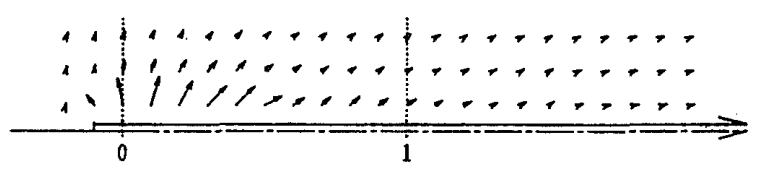

Distance from the starting point of glass fiber duct in

(a) Active intensity

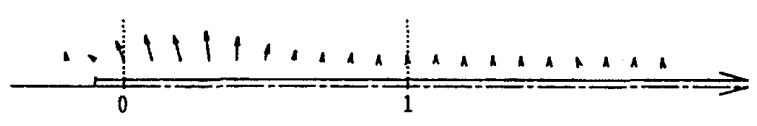

Distance from the starting point of glass fiber duct on

(b) Reactive intensity

图-17 S-300 のベクトル・マップ $(125 \mathrm{~Hz})$

こない。そこで，ここでは 1 列目のみ表示する。

図一6および 9 に示す R-200 および 300 の $125 \mathrm{~Hz}$ 帯 域では，アクティブ・インテンシティのみを見れば，ほ ほ $1 \mathrm{~m}$ 以内で音響放射が行われており $1 \mathrm{~m}$ 以降は不明 瞭であるが，リアクティブ・インテンシティを見れば 1 $\mathrm{m}$ 以降もべクトルの放射"1.'が見られる。これは，図一2 に示す R-200 および 300 の $125 \mathrm{~Hz}$ 帯域における $1 \mathrm{~m}$ 以

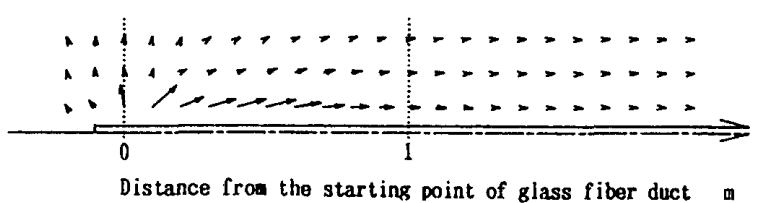

(a) Active intensity

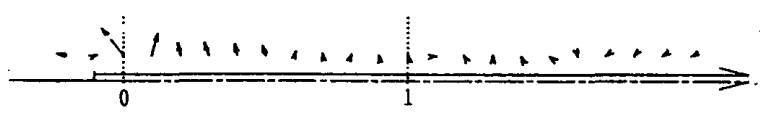

Distance from the starting point of glass riber duct a (b) Reactive intensity

图-18 S-300 のベクトル・マップ $(1 \mathrm{kHz})$

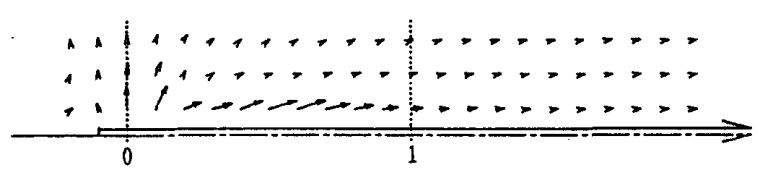

Distance from the starting point of glass fiber duct in

(a) Active intensity

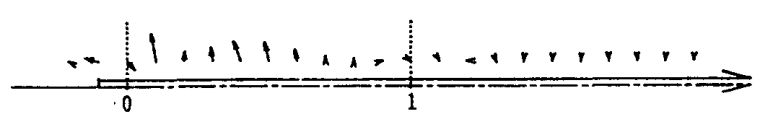

Distance from the starting point of glass fiber duct on (b) Reactive intensity

図-19 S-300のベクトル・マップ $(2 \mathrm{kHz})$

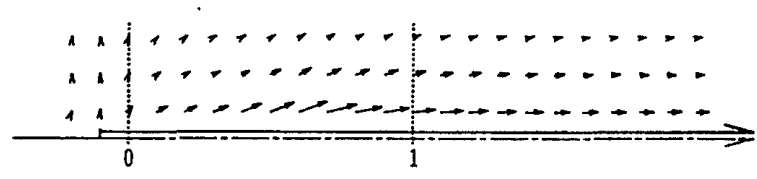

Distance from the starting point of glass fiber duct m

(a) Active intensity

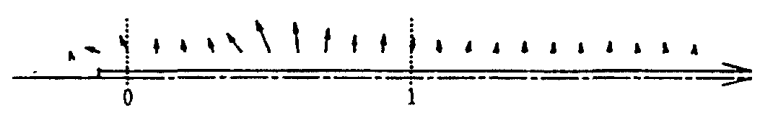

Distance from the starting point of glass fiber duct in (b) Reactive intensity

図-20 S-600 のベクトル・マップ $(500 \mathrm{~Hz})$

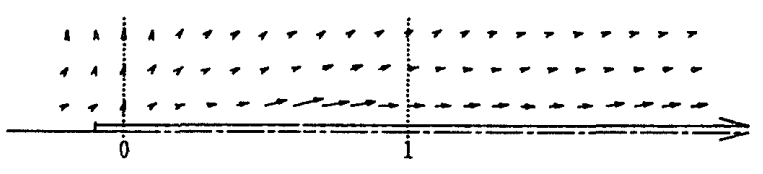

Distance from the starting point of glass fiber duct a

(a) Active intensity

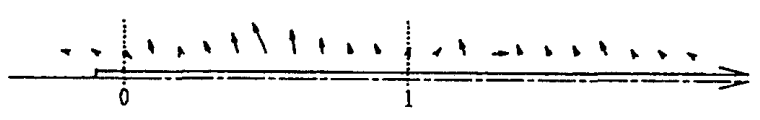

Distance from the starting point of glass fiber duct m (b) Reactive intensity

图-21 S-600のベクトル・マップ $(2 \mathrm{kHz})$

内と以降との音響減衰がほぼ等しい（レベル的には，い ずれもほとんど $0 \mathrm{~dB}$ である)ことと対応する。これに 対して，図一14 および 17 に示すS-200および 300 の $125 \mathrm{~Hz}$ 帯域では, アクティブおよびリアクティブ・イ ンテンシティいずれもほぼ $1 \mathrm{~m}$ 以内でベクトルの放射 が見られる。これは，図一 3 に示す S-200および 300 の $125 \mathrm{~Hz}$ 帯域における $1 \mathrm{~m}$ 以内の音響減衰が $1 \mathrm{~m}$ 以降の 
それより数 $\mathrm{dB}$ 大きいことと対応する。

$\mathrm{R}-200$ および S-200の 500 および $2 \mathrm{kHz}$ 帯域，R-300 および S-300の $1 \mathrm{k}$ およ゙ $2 \mathrm{kHz}$ 帯域は, アクティブお よびリアクティブ・インテンシティいずれもベクトルの 放射は，ほぼ $1 \mathrm{~m}$ 以内で大きく行われている。

また，R-600 および S-600の 500 Hz 帯域は，図一2 に示す前者の $1 \mathrm{~m}$ 以内と以降との音響诚衰は等しいが, アクティブおよびリアクティブ・インテンシティいずれ もほぼ $1 \mathrm{~m}$ 以内でベクトルの放射が見られる。 R-600 およびS-600の $2 \mathrm{kHz}$ 帯域では，前者はリアグティブ・ インテンシティを見れば $1 \mathrm{~m}$ 以内および以降いずれも ベクトルの放射が見られる。後者は，リアグティブ・イ ンテンシティにおいては前者ほど特徴がないが，アク ティブ・インテシシティにおける壁面に対して垂直方向 のベクトルの放射が小さい。ここうは，1 $\mathrm{m}$ 以内と以降 との音響減衰がほぼ等しいことと対応する。

このように, 音響減衰とベクトル・マップとの特徵が すべて対応しているわけではないが，いずれにしても， 音響減衰あるいはダクト内から外の遮音特性を考える場 合に用いた $1 \mathrm{~m}$ という距離は妥当と考えられる。

\section{4. 供試体の諸特性}

今回の供試体は，断面形状が，円形，多角形（正十角 形）および正方形の 3 種類ある。

グラス・ファイバ・ボードを現場で加工して製作でき る正方形あるいは長方形断面ダクトに比べて，円形断面 ダクトは，初めから工場で製作して現場に運ばなければ ならず，運搬に際し非常にかさばる。正方形断面ダクト と同様に製作できる多角形断面ダク卜は，このような円 形断面ダクトの不便さを解消でき，かつ円形断面ダクト により近い性能が得られるものとして開発された。

そこで，この多角形断面ダクトの音響特性を明らかに し，円形断面および正方形断面ダクトとともに 3 種類の 寸法 (200，300および 600) に統一して（网形は直径， 多角形は内接する円の直径, 正方形は一辺の長さ), 断 面形状の違いによる音響特性の比較検討をした。

今回の供試体について, 既報" で示した実験方法で求 めた音響诚衰および遮音特性を以下に示す。

\section{1. 音響減衰}

供試体を鉄板ダクトと接続したとき, 鉄板ダクトと接 続してから $1 \mathrm{~m}$ 以降の音響減衰の傾きから求めた単位 長さ $(1 \mathrm{~m})$ 当たりの音響诚衰を図一 22 2 24 に示す。断 面寸法 200 のグループでは $1 \mathrm{k}$ および $2 \mathrm{kHz}$ 帯域, 300 のグループでは $1 \mathrm{kHz}$. 帯域, 600 のグループでは $500 \mathrm{~Hz}$ 帯域で，いずれも円形断面ダクトが大きい減衰量を示す が,他の周波数帯域では 3 者ともほぼ同様な傾向を示す。

また, 鉄板ダクト接続直後 $1 \mathrm{~m}$ までの音響減衰を図 一25 27.に示す。上記の $1 \mathrm{~m}$ 以降の音響堿衰と同様に,

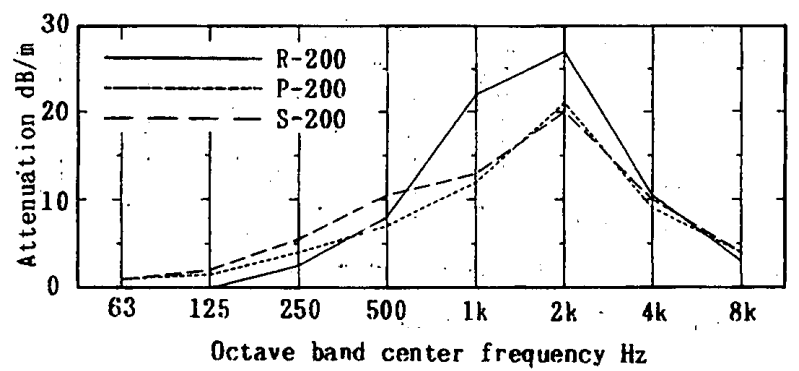

図一22 単位長さ $(1 \mathrm{~m})$ 当たりの音響娍衰 $(200)$

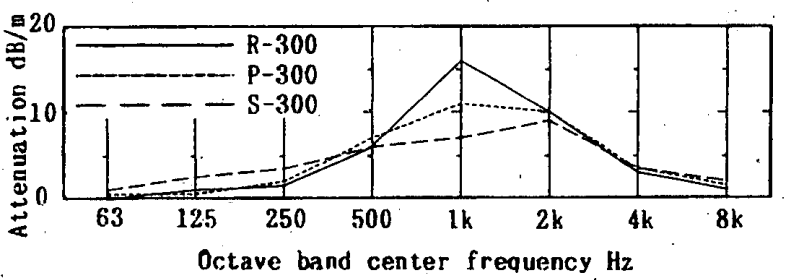

図一23 单位長さ $(1 \mathrm{~m})$ 当たりの音響诚衰 $(300)^{\prime}$

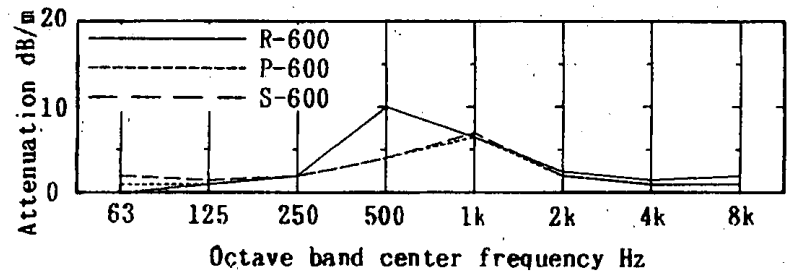

図一24 単位長さ $(1 \mathrm{~m})$ 当たりの音響減衰 $(600)$

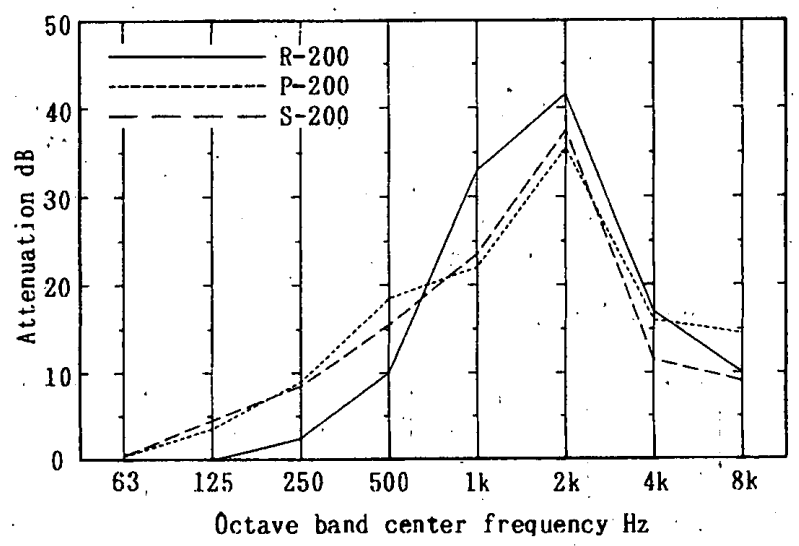

図一25鉄板ダクト接続直後 $1 \mathrm{~m}$ の音響减衰 (200)

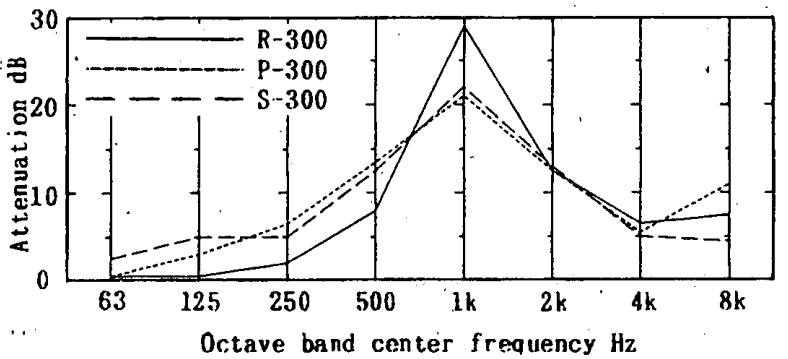

図一26鉄板ダクト接続直後 $1 \mathrm{~m}$ の音響娍衰 (300)

200 のグループでは $1 \mathrm{k}$ および $2 \mathrm{kHz}$ 帯域で, 300 のグ ループでは $1 \mathrm{kHz}$ 帯域で円形断面ダクトが大きい减衰 量を示すが，125～500 Hz 帯域では，逆に円形断面ダク トが他の 2 者に比べて減衰量が小さい。600のグループ 


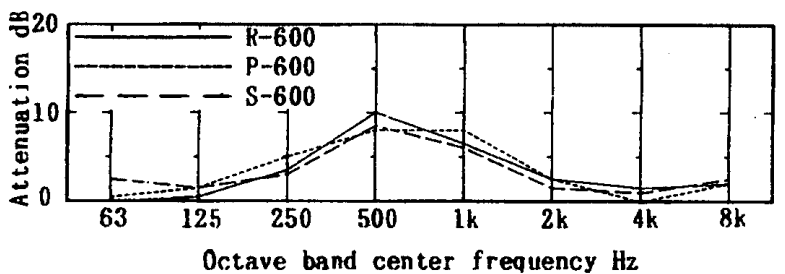

図一27鉄板ダクト接続直後 $1 \mathrm{~m}$ の音響诚衰 $(600)$

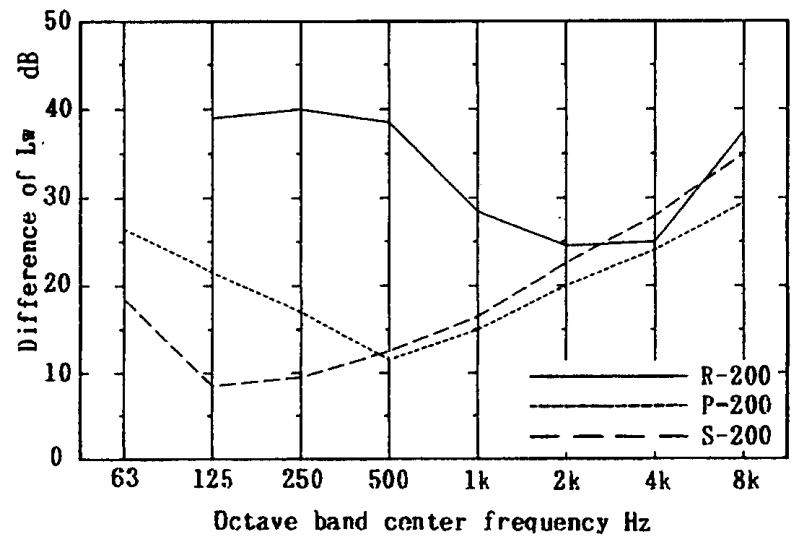

図一28 ダクト内から外へ透過する場合の遮音特性（200）

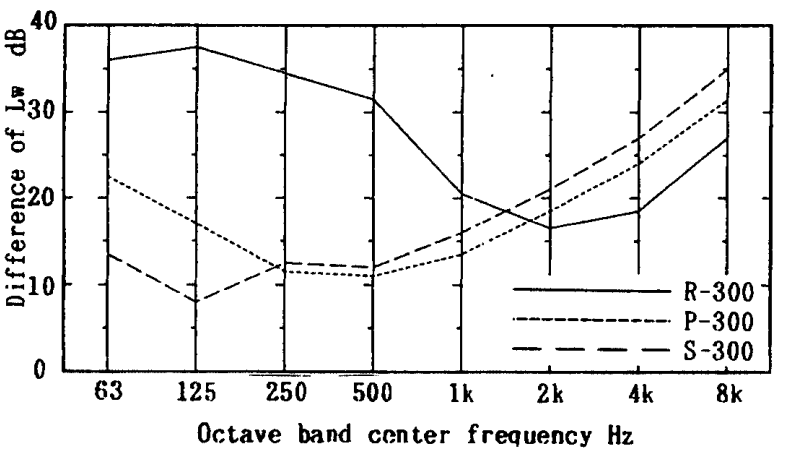

図一29 ダクト内から外へ透過する場合の遮音特性（300）

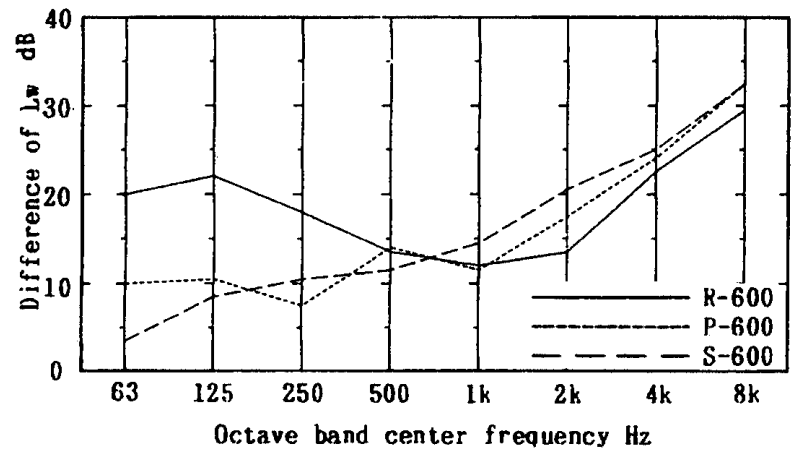

図一-30 ダクト内から外へ透過する場合の遮音特性（600）

では 3 者ともほぼ同様な傾向を示す。

全体的に見て, 多角形断面ダクトの音響減衰は, 円形 断面ダクトのそれより正方形断面ダクトのそれに近い值 を示す傾向にある。

4.2 遮音特性

鉄板ダクトに接続したとき，鉄板ダクトから供試体へ の入射パワーレベルと鉄板ダクトと接続されてから $1 \mathrm{~m}$ 以内のダクト側壁からの透過パワーレベルとの差を図-

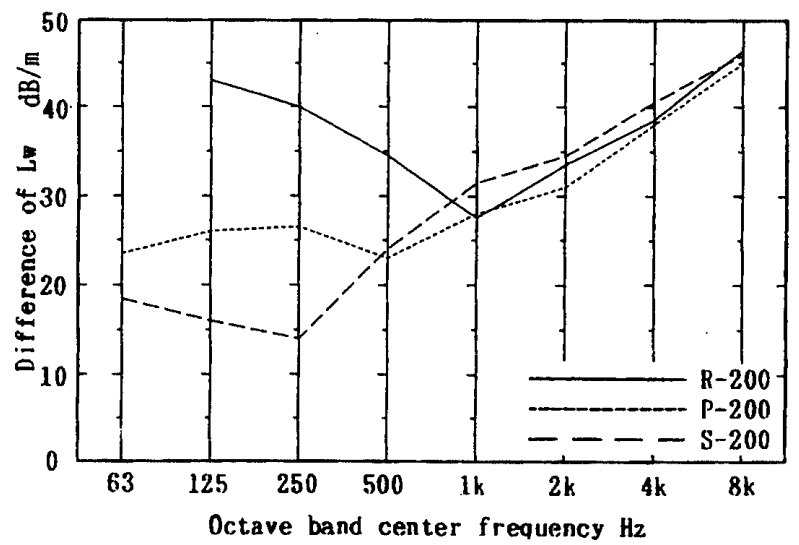

図一31 ダクト外から内へ透過する場合の遮音特性（200）

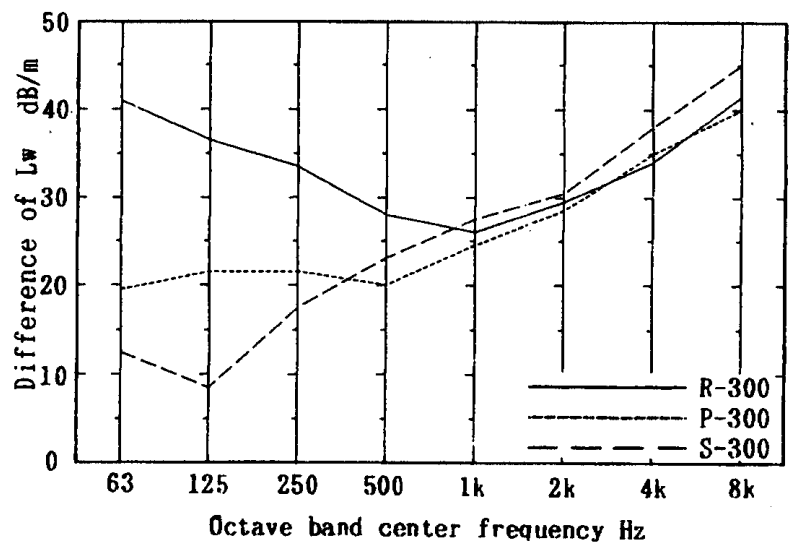

図一32 ダクト外から内へ透過する場合の遮音特性（300）

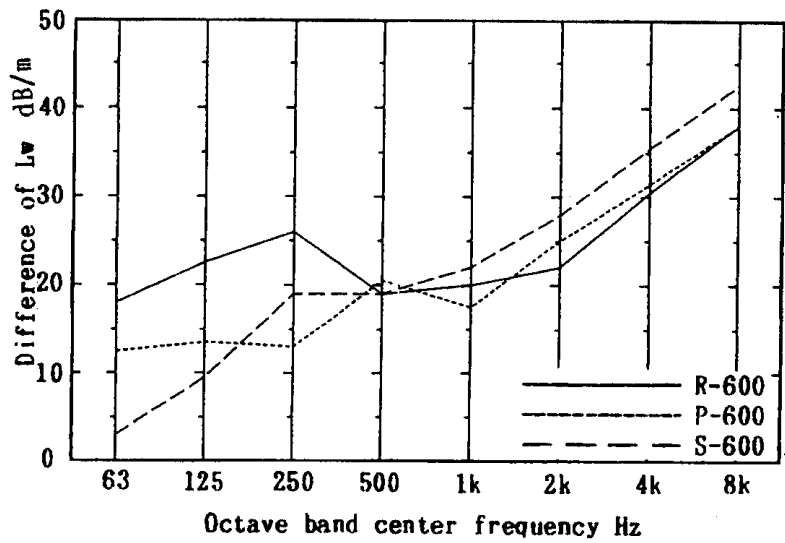

図一33 ダクト外から内へ透過する場合の遮音特性（600）

28３0に示す。断面寸法 200 および 300 のグループで は $1 \mathrm{kHz}$ 帯域以下で円形断面ダクトが他の 2 者に比べ てかなり大きな值を示し，600のグループにおいても $250 \mathrm{~Hz}$ 带域以下でほぼ同様な傾向を示す。低音域では 円形，多角形，正方形の順で値が小さくなり，断面寸法 が大きくなるに従って，3者の值の差が小さくなる。高 音域では，低音域ほよ゙の差は 3 者にはないが，200のグ ループを除けば $2 \mathrm{kHz}$ 帯域以上では正方形，多角形, 円形の順で値が小さくなる。

ダクト外からダクト長 $4.6 \mathrm{~m}$ の供試ダクト側壁への 入射パワーレベルとダクト内パワーレベルとの差から単 
位長さ $(1 \mathrm{~m})$ 当たりのパワーレベル差を求めたものを 図一31 -33 に示す。傾向としては，ダクト内から外の 遮音特性とほぼ同様である。断面寸法 200 および 300 の グループでは $500 \mathrm{~Hz}$ 帯域以下で円形断面ダクトが他の 2 者に比べてかなり大きな值を示し，低音域にいくに 従って值が大きくなる。低音域では，円形，多角形，正 方形の順で値が小さくなり，断面寸法が大きくなるに 従って，3者の值の差が小さくなる。高音域では, 比較 的 3 者の差は小さく，ほぼ同様な傾向を示す。

全体的に見て, 多角形断面ダクトの遮音特性は, 音響 減衰と同样に，円形断面ダクトのそれより正方形断面ダ クトのそれに近い值を示す傾向にある。

\section{5. 結 論}

今回実験を行ったグラス・ファイバ・ダクト直管部の 特徵を以下にまとめる。

1）断面寸法が小さい 200 および 300 では, 円形断面ダ クトが $500 \mathrm{~Hz}$ 帯域以上で，正方形断面ダクトが $125 \mathrm{~Hz}$ 帯域以上で，鉄板ダクト接続 $1 \mathrm{~m}$ 以降上り以内の音響 減衰が大きくなる。これらの特徴は,グラス・ファイバ . ダクト側壁からの音響放射におけるインテンシティのベ クトル・マップにも現れている。

2）音響減衰とベクトル・マップとの特徵がすべて対応 しているわけではないが, ベクトル・マップからも音響 減衰あるいはダクト内から外の遮音特性を考える場合に 用いた $1 \mathrm{~m}$ という距離は妥当と考えられる。

3）鉄板ダクト接続 $1 \mathrm{~m}$ 以降の単位長さ $(1 \mathrm{~m})$ 当たり の音響減衰は，断面寸法 200 のグループでは $1 \mathrm{k}$ および $2 \mathrm{kHz}$ 帯域, 300 のグループでは $1 \mathrm{kHz}$ 帯域, 600 のグ ループでは $500 \mathrm{~Hz}$ 帯域で，いずれも円形断面ダクトが 大きい堿衰量を示すが, 他の周波数帯域では 3 者ともほ ぼ同様な傾向を示す。

4）鉄板ダクト接続直後 $1 \mathrm{~m}$ までの音響減衰は， $1 \mathrm{~m}$ 以 降の音響减衰と同様に，200のグループでは $1 \mathrm{k}$ およ゙ $2 \mathrm{kHz}$ 帯域で, 300 のグループでは $1 \mathrm{kHz}$ 帯域で円形断 面ダクトが大きい減衰量を示すが, $125 〜 500 \mathrm{~Hz}$ 帯域に おいては，逆に円形断面ダクトが他の 2 者に比べて诚衰 量が小さい。600のグループでは 3 者ともほぼ同様な傾 向を示す。

5）ダクト側壁の遮音特性では，ダクト内から外あるい は外から内いずれにおいても, 低音域では円形, 多角形, 正方形の順で值が小さくなり，断面寸法が大きくなるに 従って，3 者の値の差が小さくなる。高音域では，比較 的 3 者の差は小さく、ほほほ同様な傾向を示す。

6）多角形断面ダクトは，音響特性において円形断面ダ
クトにより近い性能が得られるものとして開発された が, その性能は正方形断面ダクトに近く, 円形断面ダク トと同様の性能として使用するのは危険である。

\section{謝 辞}

本研究にあたり，グラスロン・ダクト K. K. の加藤孝 義氏，マイクロ・ダクト・システム K.K. の田村浩一氏 に多大のご協力をいただいた。また，本実験において， 当時日本大学の大学院生, 卒論生諸君の労を多しした。 ここに記して深謝する。

注

1）本論文では，参考文献4）を参照して，ベクトル・マッ プでベクトルが放射状になっている場合, ベクトルの放 射という表現を用いている。これは，アクティブ・イン テンシティの場合，音響放射として扱うことができるが， リアクティブ・インテンシティの場合, 前者と異なり, それ自体を一言で表現しがたいからである。リアクティ ブ・インテンシティは，定在波音場や音源近傍などで存 在し、ベクトルが放射状に現れている場合などは音源位 置が同定できる。

\section{参考文献}

1）板本守正，塩川博義：グラス・ファイバ・ダク卜直管部, 曲管部および分岐部の気流および音響特性について，日 本建築学会計画系論文報告集, 第 397 号, pp. 9 22, 1989. 3

2）板本守正，塩川博義：グラス・ファイバ・ダクト直管部 の気流による発生騒音について, 日本建築学会計画系論 文報告集，第 428 号，pp. $21 \sim 27,1991.10$

3）板本守正, 塩川博義：グラス・ファイバ・ダクトを吸音 体として用いたセル型消音器の気流および音響特性につ いて, 日本建築学会計画系論文報告集, 第 441 号, pp. 1 $\sim 8,1992.11$

4）日高新人, 安久司郎, 橘 秀樹：複素音響インテンシティ による音場解析, 日本音響学会誌, 43 巻 12 号, pp. 994 $\sim 1000,1987.12$

5）板本守正, 塩川博義：グラス・ファイバ・ダクト側壁か らの音響放射の視覚化, 日本建築学会大会学術講演梗概 集, pp. 407 408，1991.9

6) 板本守正, 塩川博義ほか 1 名：グラス・ファイバ・ダク 卜側壁からの音響放射の視覚化一その 2 円形断面直管部 について, 日本建築学会大会学術講演梗概集, pp. 141 $142,1992.8$

7）板本守正，塩川博義ほか 2 名：長方形および多角形断面 グラス・ファイバ・ダクト直管部の気流および音響特性 について, 日本建築学会大会学術講演梗概集, pp. 143一 $144,1992.8$

(1993 年 2 月 5 日原稿受理, 1993 年 8 月 26 日採用決定) 